$\xi=-1$

\title{
A Study on Policyholders' Satisfaction of Health Insurance with Special Reference to Ernakulam District, Kerala
}

\author{
Arun Vijay $^{1^{*}}$, V. Krishnaveni ${ }^{2}$ \\ ${ }^{1}$ Research Scholar, Department Of Management, Karpagam Academy Of Higher Education, Coimbatore. \\ ${ }^{2}$ Research Guide, Department Of Management, Karpagam Academy Of Higher Education, Coimbatore.
}

\begin{abstract}
Customer satisfaction plays a pivotal role in insurance business, especially health insurance business segment. It is not only indicative of customer loyalty but also helpful in identifying the needs of the customer. Unlike any other forms of insurance health insurance is most complex. Apart from the insurer and the insured, there are various components involved in health insurance mechanism such as healthcare providers like hospitals, Third Party Administrators, etc. So, customer satisfaction has a huge role in health insurance mechanism. It is important to retain the existing customer rather than attracting a new customer in the health insurance business segment, since the marketing cost and efforts required in retaining the existing customer will be less. Since private sector companies are coming out with innovative products in health insurance sector, public sector companies are facing a stiff competition. The study focuses on the customer satisfaction level of health insurance policyholders in Ernakulam district in Kerala. Since health insurance policies are based on yearly renewal basis, customer satisfaction has a lead role to play in determining the renewal of policies with the existing insurance company.
\end{abstract}

Keywords: Health insurance, customer satisfaction, policies, insurance companies.

\section{Introduction}

Insurance has a significant role to play in the economic development process. It acts as a risk protection against illness, natural disaster, theft, accident, fire etc. In India insurance has a long history. The life insurance business in India was started by Oriental Life Insurance Company Calcutta in 1818. Government of India nationalized insurance business in 1956. The liberalisation policies resulted in a sudden change in insurance industry. IRDA was formed in 1999 and in 2000 IRDA opened up the market and allowed foreign companies to enter into Indian insurance sector.

Health insurance is considered as a separate class of business by IRDA. In the last five years the health insurance industry has doubled the sales showing a significant jump from 15453 Crores to 30764.50 Crores in the period from 2012-13 to 2016-17. Because of increasing medical expenses health insurance plans help people in reducing risk factor related to economic shocks as a result of hospitalization. Multiple factors which contribute to the effective functioning of health insurance mechanism are hospitalization, healthcare service, third party administration, pharmaceuticals, surgical products, etc. Any imbalance in the system is a reflection of the discontent with health insurance services.

Satisfaction is considered as the level of comparison between perceived performance and expected performance for an individual. If the performance fails to meet the customers' needs they will become dissatisfied and if the performance meets their needs they will become satisfied. Customers are always demanding in service industries. It is important to understand the needs of the customer, since it changes from time to time. In recent years (2014-16), the market shares of private limited companies have increased from 35.90 Crores in 2014-15 to 38.04Crores in 2016-17. Public limited companies are gradually losing their market share to private sector companies. If the customer is not satisfied, there is a probability that he will choose another insurance company. So customer satisfaction has pivotal role in retaining the existing customer.

\section{Literature Review}

Latha and Annamalai (2007) analysed the personal and social factors influencing in the purchase of health insurance policies. The agent played a crucial role in marketing health insurance products. They also discussed the awareness and opinion about health insurance and health insurance practices.

Anita.J (2008), health insurance was considered as a complex version of insurance because of the never ending conflict between the insured and the insurers. Health insurance sector in India still remained an unexplored business sector.

Ruchita \& Bawa (2011) analysed the performance and prospects of health insurance in India. They also identified the factors affecting the performance of public sector insurance companies.

Kumar.P(2011) examined the customer expectation and satisfaction of insurance policyholders towards the services provided by 11 life insurance companies in India. According to the study the companies were offering different products, though they were providing similar kinds of service.

Aggarwal, Kapoor and Gupta (2013), examined the recent innovations in health insurance sector. Also, they identified the future areas for innovation in health insurance sector and associated challenges and complex issues involving health insurance.

Vazifehdust and Farokhian (2013) described the factors influencing the customer satisfaction of policyholders in insurance 
industry. Firstly the service quality factors were examined and then the customer satisfaction and other factors identified.

Thomas and Koshy (2013), according to them the three identified factors which involved the purchase of health insurance products by the consumer were personal, marketing and social. The study aimed at understanding the pattern of subscription of health insurance in different demographic groups and their awareness of health insurance.

Abaidoo (2015) aimed at identifying the customer satisfaction strategies in insurance industry for a successful implementation of business. The strategic importance of customer satisfaction to a business firm's growth largely depended on the satisfaction of the customers.

Hussen (2015) investigated the level of satisfaction and loyalty of the policyholder towards insurance companies. The study examined the customer satisfaction level through the application of two different customer satisfaction tools such as SERVQUAL and overall customer satisfaction models.

Studies focused on the satisfaction among public and private limited companies and the type of policies in health insurance sector were minimal. To fill this gap the current study has been carried out.

\section{Statement of the Problem}

The major market share in health insurance sector lies with public sector companies such as National, New India Assurance, Oriental and United India. The liberalization policies have brought significant changes in Indian insurance sector, opening it for private insurance companies. This resulted in increased competition among insurance companies. In 2014-15 the total premiums collected from health insurance business was 20096 Crores, of which public sector companies' was 12882 Crores and private companies' 7214 Crores. In 2015-16 the total business was 24849.05 Crores, of which the public limited companies contribution was 15559.03 and private companies' 9290.03 Crores. In 2016-17 the total business was 30764.50 Crores, of which public limited companies' contribution was 19064.42 and private companies' 11700.08 Crores. So, it is evident that the public sector companies are holding a major market share in health insurance sector, though their market share is on the decline. During the three years from 2014 to 2016, the market shares were $64.10,62.61$ and 61.96 respectively. It has been generally seen with group insurance policies that the percentage of deduction and claim rejection rates are less during claim settlement as compared with individual and family floater policies. Do the type of policies and declining percentage of market share have any role in the satisfaction level of policyholders? The study addresses this question.

\section{Scope of the Study}

Health insurance has become a dire necessity for the common man because of the huge hike in the medical expenses. Results of the study will be helpful for insurance companies operating in health insurance sector for improving their service quality. The study will be helpful for public limited companies to introduce different policy options based on customer demands as the private companies have already done.

\section{Profile of the Area}

Ernakulam is located at the central part of state of Kerala. It is surrounded by Thrissur district at the north, Idukki district at the east, Alapuzha and Kottayam district at the south and Lakshadweep Seaat the west. The district comprises an area of $3,068 \mathrm{~km}^{2}$. Ernakulam is occupied by 12 percent of Kerala population. The district head quarter is situated at Kakkanad and it is known as the commercial capital of Kerala. Ernakulam is the highest revenue generating district, where the highest number of super speciality hospitals are located.

\section{Objectives of the Study}

- The study aims to find out the policyholders' satisfaction with regard to private and public limited health insurers.

- The study examines the impact of different policies in achieving customer satisfaction.

\section{Research Methodology}

The study is based on descriptive research which involves primary as well as secondary data. Primary data were collected from policyholders who availed themselves of treatment from health insurance empanelled hospitals. Secondary data were collected from various journals and online resources comprising past studies on health insurance and customer satisfaction. The data were collected from 150 health insurance policyholders who belonged to various demographic profiles. The tools used for analysis included frequency percentage tests and chi-square tests.

\section{Data analysis and Interpretation}

\begin{tabular}{|c|c|c|c|c|}
\hline S.No & Particulars & Classification & $\begin{array}{l}\text { Number of } \\
\text { Respondents }\end{array}$ & Percentage \\
\hline \multirow[t]{3}{*}{1} & \multirow[t]{3}{*}{ Age } & Up to 30 & 17 & 11.33 \\
\hline & & 30 to 50 & 99 & 66.00 \\
\hline & & Above 50 & 34 & 22.66 \\
\hline \multirow[t]{2}{*}{2} & \multirow[t]{2}{*}{ Gender } & Male & 79 & 52.66 \\
\hline & & Female & 71 & 47.33 \\
\hline \multirow[t]{3}{*}{3} & \multirow[t]{3}{*}{ Area of Residence } & Urban & 42 & 28.00 \\
\hline & & Semi urban & 78 & 52.00 \\
\hline & & Rural & 30 & 20.00 \\
\hline \multirow[t]{6}{*}{4} & \multirow{6}{*}{$\begin{array}{l}\text { Education } \\
\text { Qualification }\end{array}$} & SSLC & 8 & 5.33 \\
\hline & & H.Sc & 14 & 9.33 \\
\hline & & Diploma & 23 & 15.33 \\
\hline & & Graduate & 58 & 38.66 \\
\hline & & $\begin{array}{l}\text { Post } \\
\text { Graduate }\end{array}$ & 25 & 16.66 \\
\hline & & Professional & 22 & 14.66 \\
\hline \multirow[t]{2}{*}{5} & \multirow[t]{2}{*}{ Marital Status } & Single & 19 & 12.66 \\
\hline & & Married & 131 & 87.33 \\
\hline \multirow[t]{6}{*}{6} & \multirow[t]{6}{*}{ Occupation } & Employee & 44 & 29.33 \\
\hline & & Business & 23 & 15.33 \\
\hline & & Homemaker & 16 & 10.66 \\
\hline & & Retired & 13 & 8.66 \\
\hline & & Professional & 42 & 28.00 \\
\hline & & Agriculturist & 12 & 8.00 \\
\hline \multirow[t]{3}{*}{7} & \multirow[t]{3}{*}{ Monthly Income } & Up to 40000 & 46 & 30.66 \\
\hline & & $40001-80000$ & 72 & 48.00 \\
\hline & & Above 80000 & 32 & 21.33 \\
\hline
\end{tabular}

Of the 150 policyholders, the age of a majority ranged 30 to 50 and it was 66 percent. 52.66 percent of the policyholders were male and 47.33 female. Among the policyholders a majority of them were semi-urban residents, this was 52 percent. 38.66 percent policyholders' educational qualification was graduation. Hence, most of the policyholders were graduates. Among the policyholders, a majority of them were married and it was 87.33 percent. 29.33 percent of the policyholders were employees and 28 percent professionals. The income of most of the policyholders ranged between 40000 and 80000 , which was 48 percent.

Table 2: Insurance Details

\begin{tabular}{|l|l|l|l|l|}
\hline S.No & Particulars & Classification & $\begin{array}{l}\text { No. of } \\
\text { Respondents }\end{array}$ & percentage \\
\hline \multirow{2}{*}{1} & \multirow{2}{*}{$\begin{array}{l}\text { Sum Assured } \\
\text { in Lakh) }\end{array}$} & Up to 1 & 6 & 4.00 \\
\cline { 3 - 5 } & & $1-2$ & 31 & 20.66 \\
\cline { 3 - 5 } & & $2-3$ & 72 & 48.00 \\
\cline { 3 - 5 } & & 3 and Above & 41 & 27.33 \\
\hline \multirow{2}{*}{2} & \multirow{2}{*}{ Type of Policy } & Individual & 25 & 46.66 \\
\cline { 3 - 5 } & & Family Floater Health & 60 & 40.00 \\
\hline
\end{tabular}




\begin{tabular}{|l|l|l|l|l|}
\hline \multirow{2}{*}{} & & Policy & & \\
\cline { 3 - 5 } & & Group Health Policy & 65 & 43.33 \\
\hline 3 & $\begin{array}{l}\text { Insurance } \\
\text { Company }\end{array}$ & Public Sector & 70 & 46.66 \\
\cline { 3 - 5 } & Private Sector & 80 & 53.33 \\
\hline
\end{tabular}

The sum assured plan of most policyholders ranged between 2 Lakh and 3 Lakh, which was 48 percent, followed by policyholders whose sum assured plan was above 3 Lakh, which was 27.33 percent. 43.33 percent of the policyholders have availed themselves of health insurance policy through group insurance, followed by family floater policies, which was 43.66 percent. 53.33 percent of the policyholders have purchased health insurance policy from private sector companies and 46.33 from public sector companies. Thus a majority of the policyholders were private sector insurance customers.

\section{Chi-Square on Satisfaction}

To examine if the type of insurance company was associated with the level of satisfaction, the following hypothesis was framed and tested.

$H_{o}$ : Type of insurance company is not associated with satisfaction

Table 3

\begin{tabular}{|l|l|l|l|l|}
\hline \multirow{2}{*}{ Insurance Company } & \multicolumn{3}{|c|}{ Level of Satisfaction } & \multirow{2}{*}{ Total } \\
\cline { 2 - 4 } & Low & Moderate & High & \\
\hline Public & 30 & 19 & 21 & 70 \\
\hline & $(42.9)$ & $(27.1)$ & $(30.0)$ & $(100.0)$ \\
\hline Private & 18 & 30 & 32 & 80 \\
\hline & $(22.5)$ & $(37.5)$ & $(40.0)$ & $(100.0)$ \\
\hline Total & 48 & 49 & 53 & 150 \\
\hline Df:2 & Chi-square :7.1008 & P Value: .0287 & Significant \\
\hline
\end{tabular}

Private sector health insurance policyholders have high level of satisfaction. Public sector health insurance policyholders have low level of satisfaction. Thus, it is inferred that private sector policyholders have high level of satisfaction on health insurance policies. As the calculated $\mathrm{P}$ value is less than 0.05 , there exists a highly significant association between type of insurance company and level of satisfaction. Hence, the null hypothesis is rejected. To examine if type of policy was associated with level of satisfaction, the following hypothesis was framed and tested.

\section{$H_{o}$ : Type of policy is not associated with satisfaction}

Table 4

\begin{tabular}{|l|l|l|l|l|}
\hline \multirow{2}{*}{ Type of Policy } & \multicolumn{3}{|c|}{ Level of Satisfaction } & \multirow{2}{*}{ Total } \\
\cline { 2 - 5 } & Low & Moderate & High & \\
\hline Individual Health & 8 & 13 & 4 & 25 \\
\hline & $(32.0)$ & $(52.0)$ & $(16.0)$ & $(100.0)$ \\
\hline Family Floater Health & 28 & 22 & 10 & 60 \\
\hline & $(46.7)$ & $(36.7)$ & $(16.6)$ & $(100.0)$ \\
\hline Group Insurance & 17 & 30 & 18 & 65 \\
\hline & $(26.1)$ & $(46.2)$ & $(27.7)$ & $(100.0)$ \\
\hline Total & 53 & 65 & 32 & 150 \\
\hline Df:4 & Chi-square $: 13.73$ & P Value: 0.008 & Significant \\
\hline
\end{tabular}

Group insurance policyholders have high level of satisfaction on health insurance policies. Individual policyholders have low level of satisfaction on health insurance policies. Thus, it is inferred that group insurance policyholders have high level of satisfaction on health insurance policies. As the calculated $\mathrm{P}$ value is less than 0.01 , there exists highly significant association between type of policy and level of satisfaction, Hence, the null hypothesis is rejected.

\section{Findings}

- Majority of the policyholders are aged 30-50

- Male policyholders account for 52.66 percent and female 47.33

- Majority of the policyholders reside in semi-urban areas; it is 52 percent

- 69.98 percent of the policyholders are graduates, post graduates and professionally qualified
- Majority of the policyholders are married; it is 87.33 percent

- Professionals and employees account for majority of the policyholders; it is 57.33 percent

- Most of the policyholders'(48.00 percent) monthly income ranges from 40000 to 80000

- Among the policyholders the satisfaction level is found high among private sector policyholders and low among public sector policyholders.

- The satisfaction level among group insurance policyholders is high, while that among individual policyholders is low.

- Since a majority of the policyholders are employees and professionals, 43.33 percent of the policies are group insurance policies.

- Low percentage of deduction is and better coverage are normally seen with group insurance policies; hence, it may be a reason for better satisfaction level among group policyholders.

- Policyholders show better satisfaction level with private health insurance companies; therefore, this may be a reason for considerable shift in momentum towards the market share of private sector insurance companies.

\section{Suggestions}

Health insurance is becoming one of the most dynamic and fast growing sectors in Indian insurance industry. During the last five years from 2012 to 2016 the gross premium collected jumped from 15453 Crores to 30764.50 Crores with a growth of 99.21 percent. For surviving in this highly competitive and potential environment, understanding customer needs is crucial. Various innovations in technology have brought about fundamental changes in health insurance industry. Private sector companies are promoting various innovative health policies and are following a more customer centric approach. Public sector companies are lagging behind in these sectors. For continuing their dominance in health insurance sector, the public sector companies will have to give utmost importance to customer satisfaction.

\section{Conclusion}

It is concluded that the type of policy and type of insurance company play a significant role in the satisfaction level of health insurance policyholders. Policyholders who have availed themselves of health insurance policies from private limited companies are more satisfied with the policies than those who are insured with public limited companies. In the case of type of policies also, there is a huge impact on the satisfaction level of policyholders. Group policyholders are more satisfied with health insurance compared with family floater policies and individual policies. Since satisfaction of policyholder is a major factor in renewing the policies and selection of companies, insurance companies will have to lay more emphasis on the satisfaction of policyholders.

\section{Future Scope for the Study}

The study can be taken as a reference for future studies about the influence of type of companies on satisfaction of policyholder and the impact of policies on satisfaction of policyholder. The study can be further extended by researching on various challenges or problems faced by the policyholder, factors influencing their purchasing decisions moral hazards and adverse selection issues associated with health insurance policies. 


\section{References}

[1] Abaidoo GG, "Customer Satisfaction Factors in Life Insurance Growth in Ghana (Published thesis)", Walden University, Minnesota, (2015)

[2] Hussen S, "Service Quality, Customers Satisfaction and Loyalty: A Study on Insurance Companies in Adama, Ethiopia", European Journal of Business and Management, Vol.7, No.4, (2015), pp. 269-276.

[3] Varghese T \& Koshy MP, "Determinants of Consumer Purchasing Decisions of Health Insurance Sector in Kerala (Published Thesis)", School of Management Studies Cochin University of Science and technology, Kochi, (2013).

[4] Aggarwal A, Kapoor N \& Gupta A, "Health Insurance: Innovations and Challenges Ahead", Global Journal of Management and Business Studies, Vol.3, No.5, (2013), pp.475-880.

[5] Vazifehdust H \& Farokhian S, "Factors influencing customer satisfaction with the success factors identified in the insurance industry", African Journal of Business Management, Vol.7, No.21, (2013), pp.2026-2032.

[6] Kumar P, "A Study of Customer Satisfaction of Life Insurance in India", Journal of Doctoral Studies, Vol.1, No.1-2, (2011), pp.6582.

[7] Ruchita BSK, "Performance and Prospectus of Health Insurance in India(Published Thesis)", Guru Nanak Dev University, Amritsar, (2011).

[8] Anita J, "Emerging Health Insurance in India- an Overview", 10th Global Conference of Actuaries, (2008).

[9] Latha MN \& Annamalai R, "A Study on Awareness, Satisfaction and Problems of Customers towards Health Insurance(Published Thesis)", Bharathiar University, Coimbatore, (2007).

[10] Health Insurance - Wikipedia

[11] IRDA Journals

[12] IRDA Annual Report 2016-17

[13] IRDA website 